Ciencias Marinas (1999), 25(3): 367-379

http://dx.doi.org/10.7773/cm.v25i3.717

\title{
LINEAR ALKYLBENZENE SULFONATES (LAS) AS TRACERS OF URBAN WASTE WATERS IN SHALLOW LITTORAL ECOSYSTEMS: A CASE STUDY IN THE BAY OF CÁDIZ \\ ALQUILBENCENO LINEAL SULFONATOS (LAS) COMO TRAZADORES DE AGUAS RESIDUALES URBANAS EN UN ECOSISTEMA LITORAL POCO PROFUNDO: UN CASO DE ESTUDIO EN LA BAHÍA DE CÁDIZ
}

\author{
E. González-Mazo ${ }^{1 *}$ \\ J.M. Quiroga ${ }^{2}$ \\ A. Gómez-Parra ${ }^{1}$ \\ ${ }^{1}$ Departamento de Química Física \\ Facultad de Ciencias del Mar \\ Universidad de Cádiz \\ Campus Río San Pedro s/n \\ 11510 Puerto Real, Cádiz, España \\ * E-mail: eduardo.gonzalez@uca.es \\ ${ }^{2}$ Departamento de Ingeniería Química, Tecnología de Alimentos \\ y Tecnologías del Medio Ambiente \\ Facultad de Ciencias del Mar \\ Universidad de Cádiz \\ Campus Río San Pedro s/n \\ 11510 Puerto Real, Cádiz, España
}

Recibido en septiembre de 1998; aceptado en junio de 1999

\begin{abstract}
The spatial distribution of linear alkylbenzene sulfonates (LAS) and their composition of homologues in sediments of Cádiz Bay, a semienclosed system surrounded by urbanized areas, has been studied. LAS homologues were measured in marine sediments using solid-phase extraction and reversed-phase high-perfomance liquid chromatography with spectrofluorimetric detection. Results showed that LAS, principally associated with solids in suspension and originating from the existing outlet where urban waste waters are discharged into the Sancti Petri Channel, are transported to Cádiz Bay during the ebb tide or emptying phase. The transport of solids in suspension is defined by the circulation of tidal currents and its sedimentation will be encouraged in those zones where the water has a long residence time, zones of low energy, where the accumulation of the surfactant takes place. These results enable the area of influence of the urban waste water discharge to be determined. The distribution of the various LAS homologues in the sediment samples is different from that of the commercial LAS. The greater the distance from the discharge point, the smaller the quantities of the long-chain homologues.
\end{abstract}

Key words: LAS, distribution, marine sediments, tracer. 
Ciencias Marinas, Vol. 25, No. 3, 1999

\section{RESUMEN}

Ha sido estudiada la distribución espacial de alquilbenceno lineal sulfonatos (LAS) y su composición de homólogos en sedimentos de la Bahía de Cádiz, un sistema semicerrado rodeado por áreas urbanizadas. Los homólogos del LAS fueron medidos en sedimentos marinos usando extracción en fase sólida seguida por cromatografía líquida en fase reversa con detector de fluorescencia. Los resultados mostraron que el LAS, asociado en su mayor parte con los sólidos en suspensión y que procede del vertido de aguas residuales urbanas sin tratar existente en el caño de Sancti Petri, es transportado a la Bahía de Cádiz durante el reflujo o vaciante. El transporte de los sólidos en supensión viene definido por la circulación de las corrientes de marea y su sedimentación se verá favorecida en aquellas zonas en las que el agua presente un elevado tiempo de residencia, zonas de baja energía, donde la acumulación del tensioactivo tiene lugar. Estos resultados permiten conocer la zona de influencia del vertido urbano utilizando al LAS como trazador. La distribución de los distintos homólogos del LAS en las muestras de sedimento es distinta a la del LAS comercial. A medida que la distancia al punto de vertido aumenta, la cantidad de homólogos de cadena larga que accede al sedimento es menor.

Palabras clave: LAS, distribución, sedimentos marinos, trazador.

\section{INTRODUCTION}

Surfactants are used for a variety of purposes but primarily in commercial detergents and household cleaning products. Due to this widespread use, surfactants are common constituents in municipal effluents and in the corresponding receiving fresh- and sea-water environments. For example, approximately $11 \%$ to $20 \%$ of the soluble organic content in several treated municipal effluents has been attributed to anionic surfactants (Rebhun and Manka, 1971).

Linear alkylbenzene sulfonates (LAS) are the most commonly used anionic surfactant. Although LAS are known to be biodegradable, considerable amounts of LAS have been found in rivers (Hon-nami and Hanya, 1980). There are numerous studies of their behavior in these environments (Painter and Zabel, 1988); however, LAS in marine environments have been the subject of only a few studies. Estuaries are considered to act as an efficient barrier against the release of LAS into the open sea (Terzic and Ahel, 1994).

In Tokyo Bay, almost all LAS present (97.4\%) are supplied to the estuary in the dissolved form (Takada et al., 1992a) and their degradation is intense. LAS content in the sediments of Tokyo Bay is extremely low, less

\section{INTRODUCCIÓN}

Los tensioactivos son usados para una variedad de propósitos pero principalmente en detergentes comerciales y productos de limpieza de uso doméstico. Debido a su extenso uso, los tensioactivos son constituyentes comunes en efluentes municipales y en los correspondientes medio ambientes marinos y de agua dulce que los reciben. Por ejemplo, aproximadamente entre el $11 \%$ y $20 \%$ del contenido orgánico soluble en efluentes municipales tratados fue atribuido a tensioactivos aniónicos (Rebhun y Manka, 1971).

El alquilbenceno lineal sulfonato (LAS) es el tensioactivo aniónico más usado. Aunque el LAS es un compuesto biodegradable, cantidades considerables de LAS han sido encontradas en ríos (Hon-nami y Hanya, 1980). Los estudios sobre su comportamiento en este medio son muy numerosos (Painter y Zabel, 1988); sin embargo, el LAS en el medio ambiente marino ha sido objeto de pocos estudios. Los estuarios son considerados como una barrera eficiente frente a la salida de LAS al mar abierto (Terzic y Ahel, 1994).

En la Bahía de Tokyo, casi la totalidad de LAS $(97.4 \%)$ es suministrado al estuario como forma disuelta (Takada et al., 1992a) y su degradación es intensa. En la Bahía de Tokyo los contenidos de LAS en sedimentos son extremadamente 
than $0.01 \mu \mathrm{g} / \mathrm{g}$ (Takada and Ishiwatari, 1991). However, the linear alkylbenzenes (LABs, or non-sulfonated derivatives of the process of synthesis of LAS), $10 \%$ to $80 \%$ transported in the dissolved form (Takada et al., 1992a), are only slightly degraded and are widely distributed in sediments throughout Tokyo Bay, with an average content of $1.38 \pm 0.67 \mu \mathrm{g} / \mathrm{g}$. This is the reason why some authors use LABs to evaluate the potential impact of domestic waste and synthetic detergents on coastal environments (Eganhouse et al., 1983; Chalaux et al., 1992; Takada et al., 1992a).

However, in other coastal zones (e.g., Cádiz Bay), LAS are discharged directly without any purification treatment and for the most part are associated with material in suspension, up to $60 \%$ in undissolved form (González-Mazo et al., 1998); this is in agreement with the values obtained by Terzic and Ahel (1994) for Sibenik Harbour. As a result of the shallow depth of Cádiz Bay (average water depth: $4 \mathrm{~m}$ ), LAS do not undergo sufficient microbial attack in the water column prior to their incorporation into the particulate matter. In addition, LAS reaching the bay in the precipitated and/or adsorbed phase do not easily biodegrade (Cavalli et al., 1993) and, under the reducing conditions $(\mathrm{Eh} \approx-230 \mathrm{mV}$ ) that are characteristic of these sediments, it is known that the rate of degradation of this surfactant is very low (Federle and Schwab, 1992). Therefore, the discharge of LAS in association with untreated domestic wastes into Cádiz Bay results in an accumulation of this surfactant in sediments, depending on their phase-association in the water column. Studies conducted on the adsorption of LAS in marine sediments have demonstrated that this process is intense and irreversible, and can therefore be described by Freundlich's model (Rubio et al., 1996).

Previous research (González-Mazo et al., 1998) undertaken in this zone confirms this hypothesis. LAS are distributed very widely and present concentrations in sediments several orders of magnitude higher than those found in the water column. This behavior allows LAS to be used to bajos, por debajo de $0.01 \mu \mathrm{g} / \mathrm{g}$ (Takada e Ishiwatari, 1991). Sin embargo, los alquilbencenos lineales (LABs, derivados no sulfonados en el proceso de síntesis del LAS), transportados entre el $10 \%$ y $80 \%$ en forma disuelta (Takada et al., 1992a), son ligeramente degradados y están distribuidos extensamente en sedimentos de la Bahía de Tokyo, con una media de $1.38 \pm 0.67 \mu \mathrm{g} / \mathrm{g}$. Ésta es la razón por la que estos autores emplean los LABs para evaluar el impacto potencial de aguas residuales domésticas y detergentes sintéticos sobre el medio ambiente costero (Eganhouse et al., 1983; Chalaux et al., 1992; Takada et al., 1992a).

Sin embargo, en otras zonas costeras (e.g., Bahía de Cádiz), el LAS es vertido sin depurar de forma directa y está asociado en su mayor parte con el material en suspensión, hasta el $60 \%$ en forma no disuelta (González-Mazo et al., 1998), en concordancia con los valores obtenidos por Terzic y Ahel (1994) para el puerto de Sibenik. La reducida profundidad (4 m) de la Bahía de Cádiz provoca que el LAS no reciba el suficiente ataque microbiano en la columna de agua previo a su incorporación al material particulado. Además, el LAS que alcanza la bahía en forma precipitada y/o adsorbida no es fácilmente biodegradado (Cavalli et al., 1993) y bajo condiciones reductoras $(\mathrm{Eh} \approx-230 \mathrm{mV}$ ), características de estos sedimentos, es conocido que la velocidad de degradación de este tensioactivo es muy lenta (Federle y Schwab, 1992). Por tanto, la descarga de LAS asociado con aguas residuales domésticas no tratadas provoca una acumulación de este tensioactivo en los sedimentos, dependiendo de su asociación en la columna de agua. Los estudios realizados sobre la adsorción de LAS en sedimentos marinos han demostrado que dicho proceso es intenso e irreversible y que puede ser descrito por el modelo de Freundlich (Rubio et al., 1996).

Trabajos previos (González-Mazo et al., 1998) realizados en esta zona confirman dicha hipótesis. El LAS se encuentra distribuido extensamente y presenta concentraciones en sedimento varios órdenes de magnitud superiores a las encontradas en la columna de agua. Este 
Ciencias Marinas, Vol. 25, No. 3, 1999

predict the pathways and ultimate fates of pollutants from domestic wastes. Understanding the sources, transport pathways and ultimate fate of pollutants in coastal marine systems is important for the assessment and prediction of the impact of human activity on the marine environment (Takada et al., 1992b).

The objetives of this study were: (1) to study the spatial distribution of LAS in sediment samples collected from a coastal zone (Cádiz Bay) that is subjected to the influence of untreated discharges of municipal waste waters from the urban areas nearby; and (2) to understand the extent of the influence of the urban discharge on the coastal marine area affected.

\section{MATERIAL AND METHODS}

\section{Chemicals}

The solvents used as the chromatographic eluents in the experiments were water and methanol, all of chromatography quality and purchased from Merck (Darmstadt, Germany). Sodium perchlorate was purchased from Merck. The commercial LAS with a low dialkyltetralinsulfonate (DATS) content $(<0.5 \%)$ was supplied by Petroquímica Española SA. The proportional composition of the different homologues is as follows: $\mathrm{C} 10,3.9 \%$; $\mathrm{C} 11,37.4 \%$; $\mathrm{C} 12,35.4 \%$; $\mathrm{C} 13,23.1 \%$; $\mathrm{C} 14,0.2 \%$. The $\mathrm{C} 18$ reversed-phase and strong anionic exchange minicolumns (SAX) were purchased from Supelco. The chromatographic separation was performed on a $10-\mu \mathrm{m}$, $25 \mathrm{~cm} \times 0.46 \mathrm{~cm}$ i.d., C8 column (Teknokroma).

\section{Study area}

A zone of the Gulf of Cádiz in the southwest of Spain (fig. 1) was chosen for this study, specifically the inner part of Cádiz Bay. This zone is shallow and has an area of $36.6 \mathrm{~km}^{2}$; of the total area, $49 \%$ corresponds to the intertidal zone. It is affected by strong tidal currents, which results in a high proportion of its waters being renewed. As the zone is subjected to semidiurnal tides, with tidal channels situated between intertidal zones, comportamiento permite utilizar al LAS para predecir el camino y el comportamiento final de polucionantes procedentes de aguas residuales domésticas. La comprensión del origen, rutas de transporte y comportamiento de polucionantes en sistemas marinos costeros es importante para asegurar y predecir el impacto de la actividad humana sobre el medio ambiente marino (Takada et al., 1992b).

Los objetivos de este estudio fueron: (1) estudiar la distribución espacial de LAS en muestras de sedimento tomadas en una zona costera (Bahía de Cádiz), sometida a la influencia de vertidos no tratados de aguas municipales procedentes de las poblaciones cercanas; y (2) conocer la extensión de la influencia del vertido urbano sobre la zona a la que accede.

\section{MATERIALES Y MÉTODOS}

\section{Reactivos}

Los disolventes usados en los experimentos como eluentes cromatográficos fueron agua $\mathrm{y}$ metanol, todos de calidad para cromatografía y suministrados por Merck (Darmstadt, Alemania). El perclorato sódico fue suministrado por Merck. El LAS comercial con un bajo contenido en dialquiltetralin sulfonatos (DATS, $<0.5 \%$ ) fue cedido por Petroquímica Española SA. La proporción de los diferentes homólogos es la siguiente: C10, $3.9 \%$; C11, 37.4\%; C12, 35.4\%; C13, 23.1\%; $\mathrm{C} 14,0.2 \%$. Minicolumnas de fase reversa C18 y de intercambio aniónico fuerte (SAX) fueron suministradas por Supelco. La separación cromatográfica fue realizada con una columna C8 $(10 \mu \mathrm{m}, 25 \times 0.46 \mathrm{~cm}$ d.i. $)$ de Teknokroma.

\section{Área de estudio}

Para el estudio fue escogida una zona del Golfo de Cádiz en el suroeste de España (fig. 1), la zona interna de la Bahía de Cádiz. Esta zona es poco profunda y tiene un área de $36.6 \mathrm{~km}^{2}$, de la cual un $49 \%$ corresponde a zona intermareal. Está afectada por fuertes corrientes de marea y, como resultado, son renovadas elevadas proporciones 


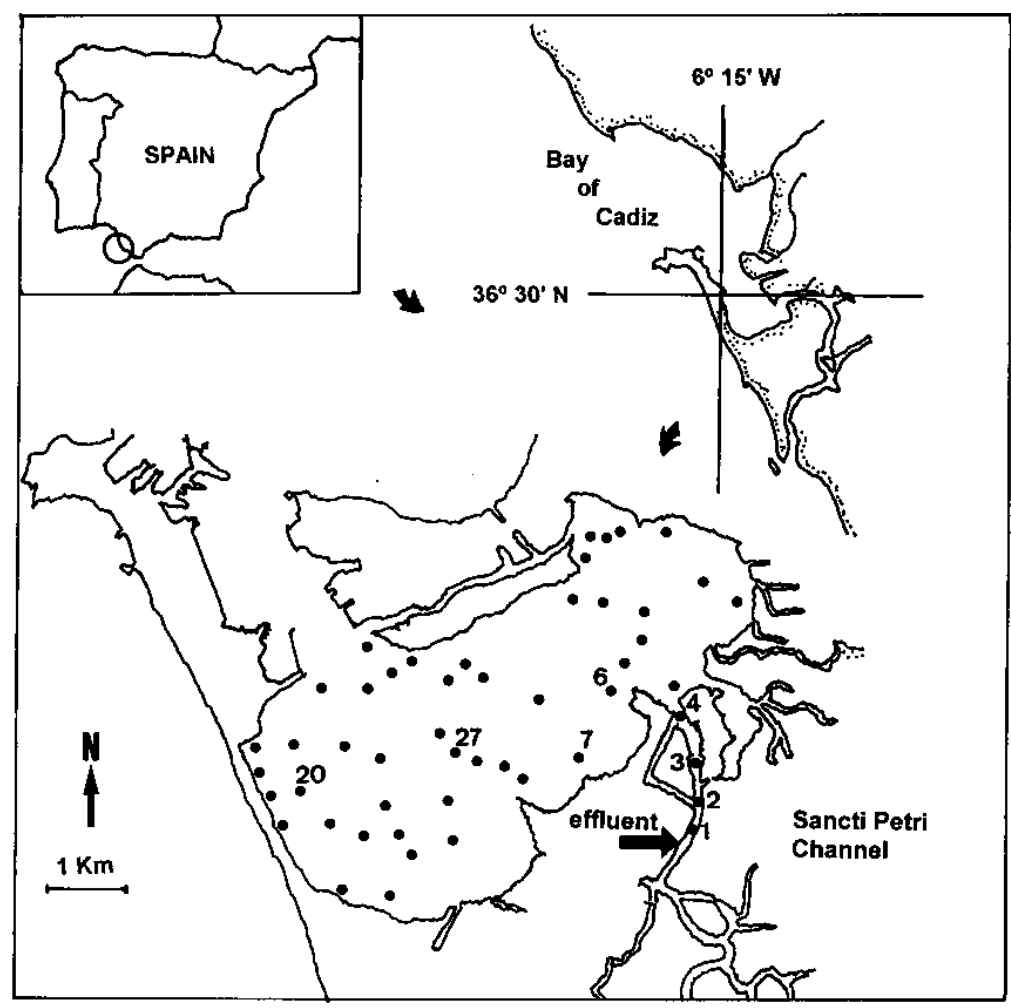

Figure 1. Map of the Bay of Cádiz showing the position of the sampling stations.

Figura 1. Mapa de la Bahía de Cádiz mostrando las posiciones de las estaciones de muestreo.

its hydrodynamics are complex. It is connected to the ocean by the Sancti Petri Channel, which is $18 \mathrm{~km}$ long and receives directly the untreated urban effluent from a population of more than 100,000 inhabitants.

The only available study of the effect of the tides on the circulation of waters in the internal part of the bay is that of Muñoz-Pérez and Sánchez-de Lamadrid (1994). The tidal regime to which this inner part of the bay is subjected is the only determining factor of the existence of tidal currents there. When the tide is both ebbing and flowing, the currents flow mainly along the navigation channel. Through this channel, the various different zones are filled and emptied. The interior zone of Cádiz Bay is a good example de sus aguas. Su hidrodinámica es compleja, como corresponde a una zona sometida a un régimen de mareas semidiurno en la que existen canales de marea situados entre zonas intermareales. Conecta con el Océano Atlántico a través del caño de Sancti Petri, que tiene una longitud de $18 \mathrm{~km}$ y que recibe directamente los efluentes de aguas residuales urbanas no tratadas de una población de más de 100,000 habitantes.

Muñoz-Pérez y Sánchez-de Lamadrid (1994) han realizado el único estudio disponible sobre el efecto de las mareas en la circulación de las aguas en el saco interior de la bahía. El régimen mareal al que se encuentra sometida la parte interior de la Bahía de Cádiz es el único factor determinante de la existencia de corrientes de 
Ciencias Marinas, Vol. 25, No. 3, 1999

of a tidal sedimentary medium, being affected by the ebb and flow of the current of water that alternatively enters and leaves the zone through the Straits of Puntales and the Sancti Petri Channel.

Sampling stations were established at the 46 locations shown in figure 1. Taking into account that municipal sewage treatment removes LAS effectively (Cavalli et al., 1993), at present the main source of LAS into Cádiz Bay is the discharge outlet for untreated domestic wastes situated in the Sancti Petri Channel (fig. 1).

\section{Sampling and pretreatment of the samples}

Samples of the surface sediments were collected using a Van Veen grab of $240 \mathrm{~cm}^{2}$ area, penetrating to a depth of between 7 and $15 \mathrm{~cm}$. They were transferred to the laboratory at a temperature of $4^{\circ} \mathrm{C}$ and kept at this temperature until the pretreatment. Then they were dried at $80^{\circ} \mathrm{C}$ in an air circulated heater and sieved through a $160-\mu \mathrm{m}$ mesh. About $15 \mathrm{~g}$ of dried sediment were extracted in a Soxhlet apparatus with $80 \mathrm{~mL}$ of methanol for 16 hours for the analysis. The extracts were evaporated to dryness under reduced pressure. In accordance with previously described procedures (González-Mazo et al., 1997b; González-Mazo et al., 1998), the residues containing LAS were dissolved in ultrapure water $(200 \mathrm{~mL})$ and acidified to $\mathrm{pH} 3$, then purified and concentrated by solid phase extraction in a C18 hydrophobic-type minicolumn and subsequently in a SAX strong anionic exchanger. The elution was carried out with $3 \mathrm{~mL}$ of $\mathrm{HCl} 2 \mathrm{~N}$ in methanol. The eluate was evaporated until dry and was redissolved in $1 \mathrm{~mL}$ of the same mobile phase used in the liquid chromatography analysis. Recovery of the LAS in the solid phase extraction stage was $96.5 \% \pm 1.5 \%$.

\section{LAS analysis}

The LAS were analyzed in a HP 1050 highperfomance liquid chromatograph equipped with marea en su interior. Tanto en el flujo como en el reflujo, las corrientes discurren principalmente por el canal de navegación. A partir de éste, se procede al llenado o vaciado de las distintas zonas. La zona interior de la Bahía de Cádiz constituye un buen ejemplo de un medio sedimentario mareal, encontrándose afectado por el flujo y el reflujo de la corriente de agua que alternativamente entra y sale por el estrecho de Puntales y el caño de Sancti Petri.

Se establecieron 46 estaciones cuya localización se muestra en la figura 1 . Teniendo en cuenta que el tratamiento de las aguas residuales municipales elimina al LAS de forma efectiva (Cavalli et al., 1993), la principal fuente de LAS a la Bahía de Cádiz son las aguas residuales domésticas no tratadas procedentes del vertido en el caño de Sancti Petri (fig. 1).

\section{Muestreo y pretratamiento de las muestras}

Las muestras de los sedimentos superficiales fueron tomadas usando una draga de $240 \mathrm{~cm}^{2}$ de área y que penetra a una profundidad de entre $7 \mathrm{y}$ $15 \mathrm{~cm}$. Fueron transportadas al laboratorio a una temperatura de $4^{\circ} \mathrm{C}$ y mantenidas hasta el análisis. Luego fueron secadas a $80^{\circ} \mathrm{C}$ en un horno y tamizadas a través de $160 \mu \mathrm{m}$. La extracción Soxhlet fue realizada sobre $15 \mathrm{~g}$ de sedimento con $80 \mathrm{~mL}$ de metanol durante 16 horas. Los extractos fueron evaporados a sequedad bajo presión reducida. De acuerdo con procedimientos descritos previamente (González-Mazo et al., 1997b; GonzálezMazo et al., 1998), los residuos conteniendo LAS fueron disueltos en agua ultrapura $(200 \mathrm{~mL})$, acidificados a $\mathrm{pH} 3$, y purificados y concentrados por extracción en fase sólida en una minicolumna de tipo hidrófobo $\mathrm{C} 18$, seguida de una de intercambio aniónico fuerte SAX. La elución fue llevada a cabo usando $3 \mathrm{~mL}$ de $\mathrm{HCl} 2 \mathrm{~N}$ en metanol. El eluato fue evaporado a sequedad y redisuelto en $1 \mathrm{~mL}$ de la misma fase móvil utilizada en el análisis por cromatografía de líquidos. La recuperación del LAS en la etapa de extracción en fase sólida fue del $96.5 \% \pm 1.5 \%$. 
a fluorescence detector $\left(\lambda_{\text {exc }}=225 \mathrm{~nm}\right.$ and $\lambda_{\text {em }}=$ $295 \mathrm{~nm}$ ) following the procedure described by González-Mazo et al. (1997a, b). Homologues were separated using a Lichrosorb RP-8 column of 250-mm length and 4.6-mm internal diameter, with a particle size of $10 \mu \mathrm{m}$, and precolumns of the same stationary phase. Sodium perchlorate $\left(10 \mathrm{~g} \times \mathrm{L}^{-1}\right)$ in methanol-water (80:20), at a flow rate of $1.0 \mathrm{~mL} \times \mathrm{min}^{-1}$, was used as eluent. LAS concentrations were determined by measuring the peak areas, using external standards. These standards were treated in the same way as the samples.

\section{RESULTS AND DISCUSSION}

Figure 2 shows the spatial distribution of the surface concentrations of LAS in sediment, found at the 46 sampling stations selected. In general, the values are low, but are two orders of magnitude greater than those found by Takada and Ishiwatari (1991). The highest values are found in the southwest and northeast of the bay, reaching concentrations greater than 7 and $5 \mu \mathrm{g} / \mathrm{g}$, respectively.

In previous studies, González-Mazo et al. (1998) have demonstrated that LAS are for the most part associated with particulate matter, which plays an important role in the transport of organic substances in the aquatic medium, due to the high specific surface presented. The transport of solids in suspension is defined by the circulation of tidal currents and its sedimentation will be encouraged in those zones where the water has a long residence time.

The studies undertaken by Muñoz-Pérez and Sánchez-de Lamadrid (1994) show that the tidal regime gives rise to currents in the bay that circulate in different directions according to the particular phase of the tide under consideration. Thus, during the flow tide, the currents flow towards the interior of the bay, whereas during the ebb tide, they flow towards the exterior. As can be observed in figure 3 , the last stage of the ebb and first stage of the flow tides occur simultaneously, producing two parallel and opposite currents: one

\section{Análisis de LAS}

El LAS fue analizado en un cromatógrafo de líquidos (HP 1050) equipado con detector de fluorescencia $\left(\lambda_{\text {exc }}=225 \mathrm{~nm}\right.$ y $\left.\lambda_{\text {em }}=295 \mathrm{~nm}\right)$ siguiendo el procedimiento descrito por González-Mazo et al. (1997a, b). Los homólogos fueron separados usando una columna Lichrosorb RP-8 de $250 \mathrm{~mm}$ de longitud y $4.6 \mathrm{~mm}$ de diámetro interno, con un tamaño de partícula de $10 \mu \mathrm{m}$, y precolumnas de la misma fase estacionaria. Como fase móvil fue usado perclorato sódico $\left(10 \mathrm{~g} \times \mathrm{L}^{-1}\right)$ en metanol-agua (80:20), a una velocidad de flujo de $1.0 \mathrm{~mL} \times \mathrm{min}^{-1}$. Las concentraciones de LAS fueron determinadas midiendo áreas de pico, usando estándar externos. Estos estándar fueron tratados de la misma forma que las muestras.

\section{RESULTADOS Y DISCUSIÓN}

En la figura 2 se muestra la distribución espacial que presenta la concentración superficial de LAS en sedimento para las 46 estaciones seleccionadas. Los valores en general son bajos, aunque dos órdenes de magnitud superiores a los encontrados por Takada e Ishiwatari (1991). Los valores más elevados se encuentran en los márgenes suroeste y noreste de la bahía, alcanzando concentraciones superiores a 7 y $5 \mu \mathrm{g} / \mathrm{g}$, respectivamente.

En estudios previos, González-Mazo et al. (1998) han demostrado que el LAS está asociado en su mayor parte con el material particulado, el cual juega un papel muy importante en el transporte de sustancias orgánicas en el medio acuático, debido a la elevada superficie específica que presenta. El transporte de los sólidos en suspensión viene definido por la circulación de las corrientes de marea y su sedimentación se verá favorecida en aquellas zonas en las que el agua presente un elevado tiempo de residencia.

Los estudios realizados por Muñoz-Pérez y Sánchez-de Lamadrid (1994) demuestran que el régimen mareal origina en la bahía corrientes en sentidos distintos según la fase de la marea que se 


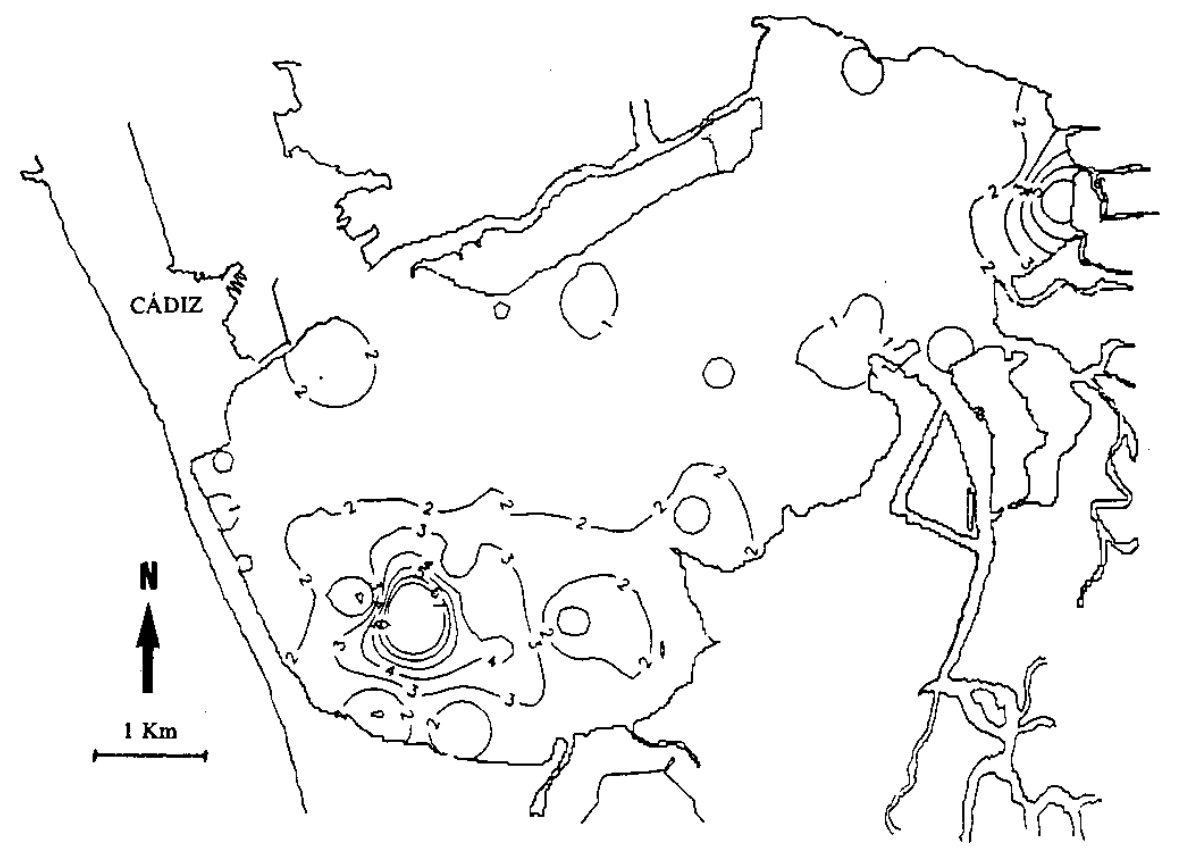

Figure 2. Spatial distribution of the surface concentrations of LAS in sediments.

Figura 2. Distribución espacial de la concentración de LAS en sedimentos.

anticyclonic from the western zone of the bay flowing towards the exterior and the other flowing along the main channel towards the interior of the bay. The last zones where the emptying and filling occur correspond to the southwest and northeast part of the bay. These zones of low kinetic energy, where the water mass presents a long residence time and the consequent sedimentation this encourages, correspond to intertidal zones.

LAS, principally associated with the solids in suspension and originating from the existing outlet where urban waste waters are discharged in the Sancti Petri Channel, are transported to Cádiz Bay during the ebb tide or emptying phase. The sedimentation of the solids in suspension occurs preferentially in the previously-described zone of low energy, where the accumulation of the surfactant takes place. considera. Así, durante el flujo, las corrientes se dirigen hacia el interior de la bahía, mientras que durante el reflujo, lo hacen hacia el exterior. Como puede observarse en la figura 3 , la última etapa del reflujo y la primera del flujo se dan simultáneamente, produciéndose dos corrientes paralelas y opuestas: una anticiclónica procedente de la zona occidental de la bahía que se dirige hacia el exterior y otra que fluye por el canal principal hacia el interior de la bahía. Las últimas zonas donde se produce el vaciado y llenado corresponden a la parte más oriental y septentrional de la bahía. Estas zonas de baja energía cinética, donde la masa de agua presenta un elevado tiempo de residencia y la sedimentación está favorecida, corresponden a zonas intermareales.

El LAS, asociado en su mayor parte con los sólidos es suspensión y que procede del vertido de 

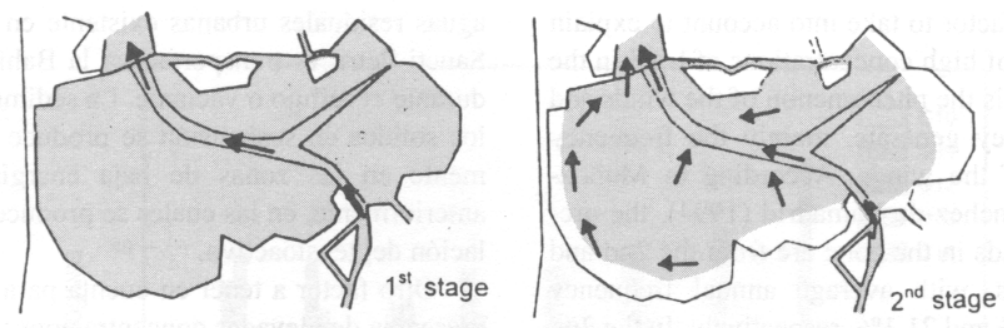

a
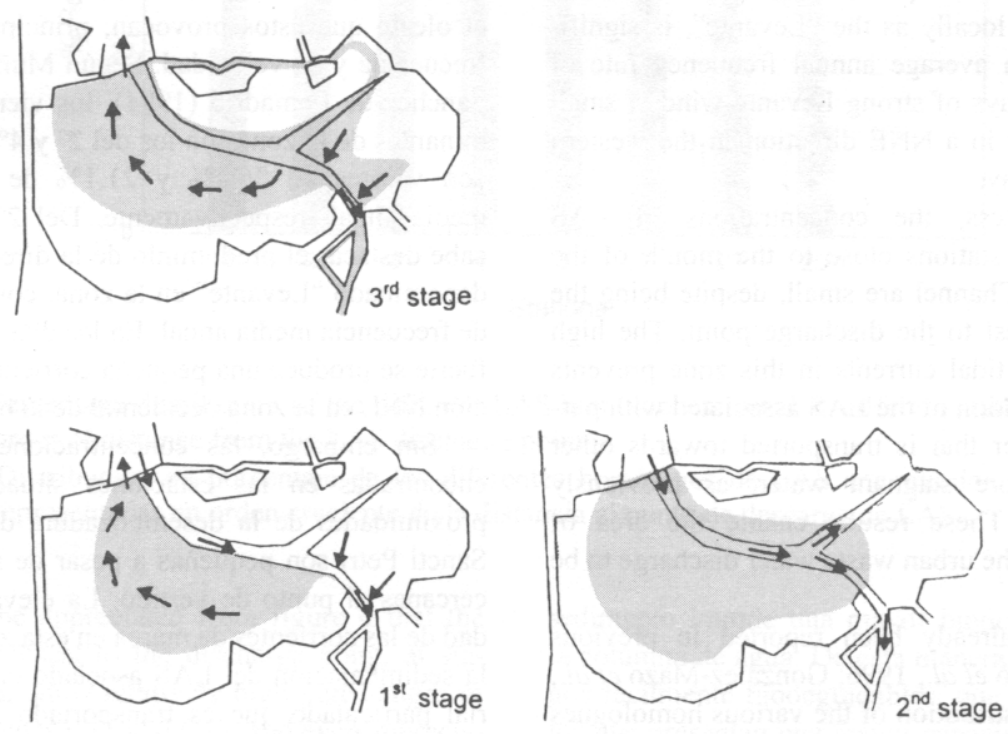

b
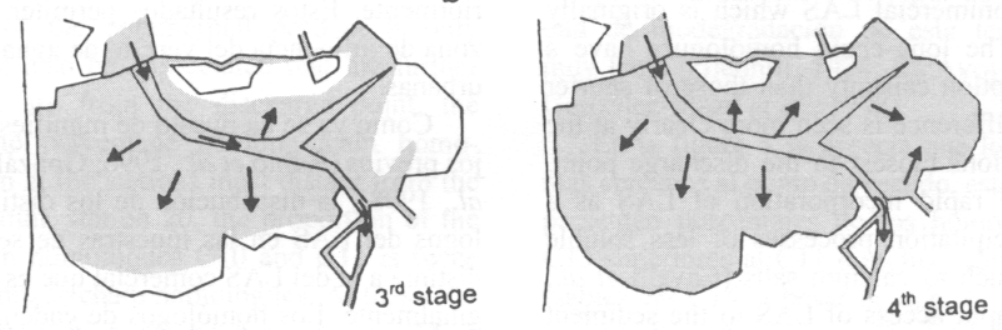

Figure 3. Schematic representation of the tidal dynamics during: (a) ebb tide or emptying phase; (b) flow tide or flowing phase. (Taken from Muñoz-Pérez and Sánchez-de Lamadrid, 1994.)

Figura 3. Representación esquemática del movimiento de las aguas durante: (a) el reflujo o vaciante; (b) el flujo o creciente. (Tomado de Muñoz-Pérez y Sánchez-de Lamadrid, 1994.) 
Ciencias Marinas, Vol. 25, No. 3, 1999

Another factor to take into account to explain the presence of high concentrations of LAS in the western zone is the phenomenon of the winds and the waves they generate, mainly the frequency and speed of the winds. According to MuñozPérez and Sánchez-de Lamadrid (1994), the predominant winds in the zone are from the 2nd and 4th quadrants, with average annual frequency rates of $26.8 \%$ and $21.1 \%$, respectively. In the 2 nd quadrant, the most predominant wind from the ESE, known locally as the "Levante", is significant, with an average annual frequency rate of $19.6 \%$. On days of strong Levante wind, a small current flows in a NNE direction in the western zone of the bay.

Nevertheless, the concentrations of LAS found at the stations close to the mouth of the Sancti Petri Channel are small, despite being the stations closest to the discharge point. The high speed of the tidal currents in this zone prevents the sedimentation of the LAS associated with particulate matter that is transported towards other zones of more stagnant water, as previously commented. These results enable the area of influence of the urban waste water discharge to be determined.

As has already been reported in previous studies (Rubio et al., 1996; González-Mazo et al., 1998), the distribution of the various homologues of LAS in the sediment samples is different from that of the commercial LAS which is originally discharged. The long-chain homologues have a greater adsorption capacity than those of shorter chain. This difference is seen more clearly at the sampling stations closest to the discharge point, owing to the rapid incorporation of LAS as a result of precipitation processes of less soluble compounds such as calcium salts (Cavalli et al., 1993). The rapid access of LAS to the sediment prevents a greater biodegradation in the water column. In this way, the more easily biodegradable homologues, which in turn are those showing a greater adsorption capacity, end up in a zone where the rate of biodegradation of this surfactant is very slow (Gledhill, 1974; McAvoy et al., 1993; González-Mazo et al., 1998). aguas residuales urbanas existente en el caño de Sancti Petri, es transportado a la Bahía de Cádiz durante el reflujo o vaciante. La sedimentación de los sólidos en suspensión se produce preferentemente en las zonas de baja energía descritas anteriormente, en las cuales se produce la acumulación del tensioactivo.

Otro factor a tener en cuenta para explicar la presencia de elevadas concentraciones de LAS en la zona occidental es el fenómeno de los vientos y el oleaje que éstos provocan, principalmente su frecuencia y su velocidad. Según Muñoz-Pérez y Sánchez-de Lamadrid (1994), los vientos predominantes de la zona son los del $2^{\circ}$ y $4^{\circ}$ cuadrante, con valores de $26.8 \%$ y $21.1 \%$ de frecuencia media anual, respectivamente. Del $2^{\circ}$ cuadrante cabe destacar el predominio de la dirección ESE, denominado "Levante" en la zona, con un $19.6 \%$ de frecuencia media anual. En los días de Levante fuerte se produce una pequeña corriente de dirección NNE en la zona occidental de la bahía.

Sin embargo, las concentraciones de LAS encontradas en las estaciones situadas en las proximidades de la desembocadura del caño de Sancti Petri son pequeñas a pesar de ser las más cercanas al punto de vertido. La elevada velocidad de las corrientes de marea en esta zona impide la sedimentación del LAS asociado con el material particulado que es transportado hacia otras zonas más remansadas, como comentamos anteriormente. Estos resultados permiten conocer la zona de influencia del vertido de aguas residuales urbanas.

Como ya se ha puesto de manifiesto en trabajos previos (Rubio et al., 1996; González-Mazo et al., 1998), la distribución de los distintos homólogos del LAS en las muestras de sedimento es distinta a la del LAS comercial que es vertido originalmente. Los homólogos de cadena larga presentan mayor capacidad de adsorción que los de menor longitud de cadena. Dicha diferencia es más acusada en las estaciones cercanas al punto de vertido, debido a la rápida incorporación del LAS por los procesos de precipitación de compuestos de menor solubilidad como sales cálcicas (Cavalli et al., 1993). El rápido acceso al 


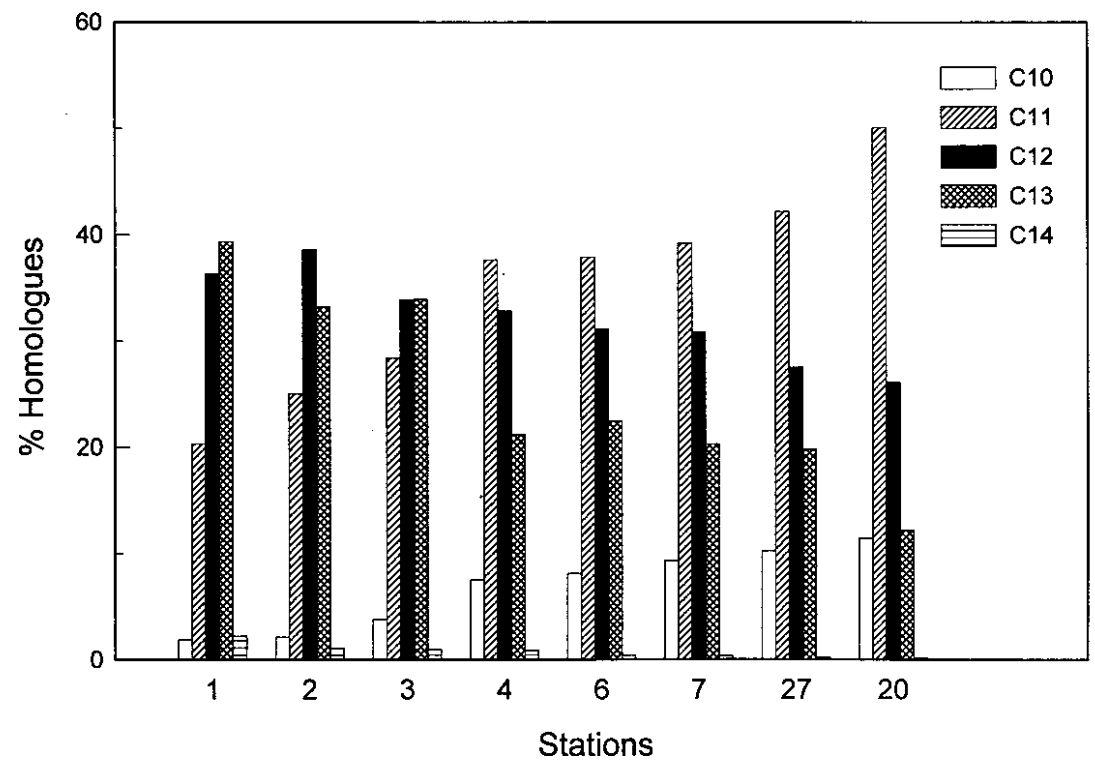

Figure 4. Percentage distribution of the different LAS homologues found at different stations, listed in increasing order of distance from the LAS discharge point.

Figura 4. Distribución en porcentaje de los diferentes homólogos de LAS encontrados en diferentes estaciones representadas en orden creciente de la distancia al punto de descarga de LAS.

It can be appreciated from figure 4 that the sediments closest to the discharge point, at stations 1 to 3 , show relatively high percentages of the homologues $\mathrm{C} 12$ and $\mathrm{C} 13$, and even appreciable quantities of $\mathrm{C} 14$, despite the fact that their proportion of the commercial product is only $0.2 \%$. It can also be appreciated that the further the stations are from the discharge point, the lower is the percentage of long-chain homologues. Even at the stations most distant from the discharge point, station 20, the proportion of the shorter-chain homologues $\mathrm{C} 10$ and $\mathrm{C} 11$ is twice that of the longer-chain homologues. At these stations, the proportion of the homologue $\mathrm{C} 14$ is scarcely appreciable at all. The long-chain homologues, which are those showing greater adsorption capacity, in turn degrade more easily than the short-chain ones. Therefore, the processes of adsorption and degradation remove or eliminate to a greater extent the homologues of longer-chain sedimento impide una mayor biodegradación en la columna de agua. De esta manera, los homólogos fácilmente biodegradables, que a su vez son los que presentan una mayor capacidad de adsorción, son conducidos a un lugar donde la velocidad de biodegradación de este tensioactivo es muy lenta (Gledhill, 1974; McAvoy et al., 1993; González-Mazo et al., 1998).

En la figura 4 se aprecia que los sedimentos más cercanos al punto de vertido, estaciones 1 a 3 , presentan porcentajes de los homólogos $\mathrm{C} 12$ y C13 superiores al C11 e incluso cantidades apreciables del $\mathrm{C} 14$, a pesar de que su proporción en el producto comercial es sólo del $0.2 \%$. A medida que las estaciones están más alejadas del punto de vertido, se aprecia que el porcentaje de los homólogos de cadena larga disminuye. Incluso en las estaciones más alejadas, estación 20, la proporción de los homólogos de cadena corta C10 y C11 es incluso dos veces superior a los de cadena 
Ciencias Marinas, Vol. 25, No. 3, 1999

while they are being transported. The greater the distance from the discharge point, the smaller the quantities of these homologues reaching the sediment.

\section{ACKNOWLEDGEMENTS}

We would like to express our gratitude to María F. Osta-Fort and Pablo Vidal-Ostenero for their assistance with the processing of the samples, and to J.L. Muñoz-Pérez and A. Sánchez-de Lamadrid for allowing us to quote from their paper on the effect of the tides on the circulation of waters in the internal part of the bay. This study was supported by a joint research program of Petroquímica Española SA, the Spanish Consejo Superior de Investigaciones Científicas (No. 3897/91) and the University of Cádiz (No. 8/91), and by the Environmental and Climate Program of the European Commission (contract No. ENV4-CT97-0494).

\section{REFERENCES}

Cavalli, L., Gellera, A. and Landone, A. (1993). LAS removal and biodegradation in a wastewater treatment plant. Environ. Toxicol. Chem., 12: 1777-1788.

Chalaux, N., Bayona, J.M., Venkatesan, M.I. and Albaiges, J. (1992). Distribution of surfactant markers in sediments from Santa Monica basin, Southern California. Mar. Pollut. Bull., 24(8): 403-407.

Eganhouse, R.P., Blumfield, D.L. and Kaplan, I.R. (1983). Long-chain alkylbenzenes as molecular tracers of domestic wastes in the marine environment. Environ. Sci. Technol., 17: 523-530.

Federle, T.W. and Schwab, B.S. (1992) Mineralization of surfactants in anaerobic sediments of a laundromat wastewater pond. Wat. Res., 26(1): 123-127.

Gledhill, W.E. (1974). Linear alkylbenzene sulphonate: Biodegradation and aquatic interactions. Appl. Microbiol., 17: 265-293.

González-Mazo, E., Honing, M., Barceló, D. and Gómez-Parra, A. (1997a). Monitoring long-chain intermediate products from the degradation of linear alkylbenzene sulfonates in the marine larga. En dichas estaciones, la proporción del homólogo C14 es prácticamente inapreciable. Los homólogos de cadena larga, que son los que presentan mayor capacidad de adsorción, a su vez se degradan más fácilmente que los de cadena corta. Por tanto, los procesos de adsorción y degradación retirarán en mayor cuantía a los homólogos de cadena larga durante su transporte. A medida que la distancia del punto de vertido aumenta, la cantidad de estos homólogos que accede al sedimento es menor.

\section{AGRADECIMIENTOS}

Los autores agradecen a María F. Osta-Fort y a Pablo Vidal-Ostenero su ayuda en la toma y analísis de las muestras. También agradecen a J.L. Muñoz-Pérez y A. Sánchez-de Lamadrid su autorización para citar su trabajo sobre el efecto de las mareas en la circulación de las aguas en el saco interior de la bahía. El trabajo descrito fue realizado como parte del proyecto de investigación entre Petroquímica Española SA, el Consejo Superior de Investigaciones Científicas (No. 3897/91) y la Universidad de Cádiz (No. 8/91), y del proyecto ENV4-CT97-0494, financiado por la Comunidad Europea.

Traducido al español por los autores.

environment by solid-phase extraction followed by liquid chromatography/ionspray mass spectrometry. Environ. Sci. Technol., 31(2): 504-510.

González-Mazo, E., Quiroga, J.M., Sales, D. and Gómez-Parra, A. (1997b). Levels of linear alkylbenzene sulfonate (LAS) in waters and sediments of the coastal ecosystems of the Gulf of Cadiz. Toxicol. Environ. Chem., 59: 77-87.

González-Mazo, E., Forja, J.M. and Gómez-Parra, A. (1998). Fate and distribution of linear alkylbenzene sulfonates in the littoral environment. Environ. Sci. Technol., 32: 1636-1641.

Hon-nami, H. and Hanya, T. (1980). Difference in the composition of linear alkylbenzene sulfonate homologues in river sediment and river water. Jap. J. Limnol., 41(1): 1-4. 
McAvoy, D.C., Eckhoff, W.S. and Rapaport, R.A (1993). Fate of linear alkylbenzene sulfonate in the environment. Environ. Toxicol. Chem., 12: 977-987.

Muñoz-Pérez, J.L. y Sánchez-de Lamadrid, A. (1994). El medio físico y biológico en la Bahía de Cádiz: saco interior. Junta de Andalucía. Conserjería de Agricultura y Pesca. Informaciones técnicas 28/94, $161 \mathrm{pp}$.

Painter, H.A. and Zabel, T.H. (1988). Review of the environmental safety of LAS. Water Research Centre Medmenham, Marlow, Bucks., UK, 232 pp.

Rebhun, M. and Manka, J. (1971). Classification of organics in secondary effluents. Environ. Sci. Technol., 7: 606-609.

Rubio, J.A., González-Mazo, E. and Gómez-Parra, A. (1996). Sorption of linear alkylbenzene sulfonates (LAS) on marine sediment. Mar. Chem., 54: 171-177.
Takada, H. and Ishiwatari, R. (1991). Linear alkylbenzenes (LABs) in urban riverine and coastal sediments and their usefulness as a molecular indicator of domestic wastes. Wat. Sci. Tech., 23: 437-446.

Takada, H., Ogura, N. and Ishiwatari, R. (1992a). Seasonal variations and modes of riverine input of organic pollutants to the coastal zone. 1. Flux of detergent-derived pollutants to Tokyo Bay. Environ. Sci. Technol., 26(12): 2517-2523.

Takada, H., Ishiwatari, R. and Ogura, N. (1992b). Distribution of linear alkylbenzenes (LABs) and linear alkylbenzene sulphonates (LAS) in Tokyo Bay sediments. Estuar. Coast. Shelf Sci., 35: 141-156.

Terzic, S. and Ahel, M. (1994). Input and behaviour of linear alkylbenzene sulphonates (LAS) in a stratified estuary. Mar. Pollut. Bull., 28(12): 735-740. 